\title{
Die heuristiese potensiaal van narratiwiteit vir sosiaal relevante Sistematiese Teologie: Jürgen Moltmann se oorlogservarings as voorbeeldstudie
}

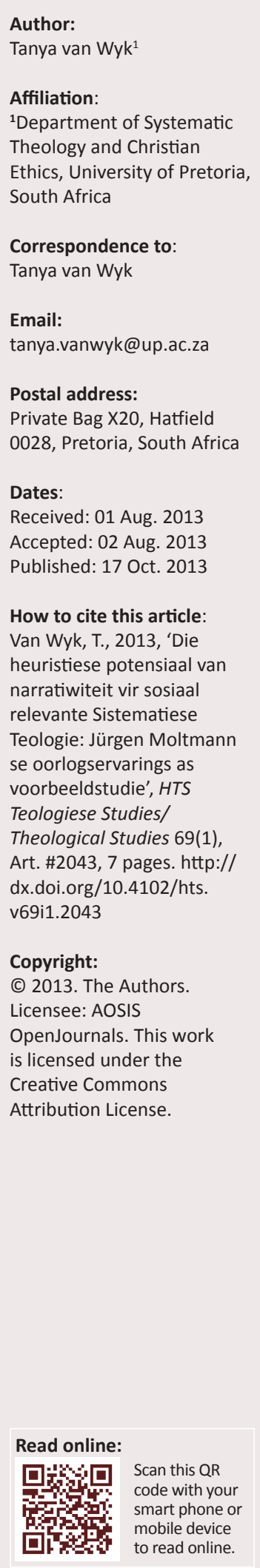

The heuristic potential of narrativity for socially relevant Systematic Theology: The world war experiences of Jürgen Moltmann as case study. The article argues that an argumentative discourse should be complemented by a narrative discursive mode to express the connectedness between experience and the social context in which people's life history is embedded. The article's point of departure is Jean-Baptisté Metz's notion of the 'practical, liberating character of narrative'. An example of such a narrative systematic discourse is the approach of Michael Weinrich in which he replaces logos (ratio) with mythosis. The latter includes narratio, whilst logos does not. The life history of Jürgen Moltmann as contextual theologian serves as case study to demonstrate the heuristic potential of narrativity for contextual systematic theology. Moltmann's autobiography The Broad Place functions as the frame of reference for such a narrative approach to systematic theology.

\section{'n Teologie van die lewe Ervaring, narratief en etiek}

Teologiebeoefening as narratief is vir sistematiese teoloë nie ' $n$ vanselfsprekende metodologie nie (vgl. McClendon [1974] 1990:ix; 1). In Duitsland (kyk Mauz 2009:265-285) kan die debat hieroor na die Mei 1973-uitgawe van die tydskrif Concilium teruggespoor word. Die tema van hierdie uitgawe was 'The crisis of religious language'. In hierdie uitgawe het die linguis Harald Weinrich (1973:1) die 'kompositum' narratiewe teologie vir die eerste keer gebruik. ${ }^{1}$ Ook Johann Baptist Metz (1973:334-342) het in die uitgawe oor narratiwiteit geskryf. Onderskeidelik het hierdie twee teoloë op verskillende aspekte gefokus. Metz het 'narratiewe teologie' binne die breër konteks van politieke teologie geplaas as 'n modus van teologie wat sensitief is vir die ervaring van mense, veral lyding (Metz 1973:339). Dit beteken egter nie dat Metz nie meer plek vir die argumentatiewe modus in teologiebeoefening gegee het nie. Hy meen egter wel dat 'argumentatiewe teologie' gerelativeer behoort te word (Metz 1973:340). Daar is 'n nou relasie tussen ervaring en narratief, en hy sien dit in die teologiebeoefening van Martin Buber en Ernst Bloch, wat hy beskryf as die 'practical, liberating character of narrative' (Metz 1973:335). Weinrich se benadering tot narratiewe teologie is histories. Die 'narratiewe kwaliteit' van die Christendom word volgens hom in die Bybel gevind, maar hierdie 'narratiewe kwaliteit' het egter toenemend afgeneem (Weinrich 1973:331). Mythos is met logos vervang ${ }^{2}$ en sodoende het die Christelike teologiese tradisie in die rigting beweeg van 'armies of other philosophers [...] who see their task as the construction of systems and theories, as reasoning and debate' (Weinrich 1973:331). Rede (logos) het narratio uitgesluit. Hierdie vooroordeel teenoor die begrip 'narratiwiteit' het in hedendaagse teologiebeoefening steeds 'n 'na-lewe', in die sin dat daar neergesien word op sake wat nie die 'toets van die wetenskap' (instrumentele rasionaliteit), volgens modernistiese kriteria, slaag nie.

In sy oorsig oor 'narratiewe teologie' in die Duitssprekende wêreld wys Mauz (2009:268-271) op die vooroordele van twee Duitse sistematiese teoloë teen 'narratiewe teologie', naamlik Dietrich Ritschl (1976, 1984, 2005) en Eberhard Jüngel (1974, [1977] 1992). Ritschl (1976:18) verwys na 'narratiewe teologie' as 'daardie idioom' (Mauz 2009:269). Hy het nie 'n belang in teologie wat met lewenservaring en sosiale relevansie te doen het nie; sake wat veral met behulp van 'n narratief-diskursiewe metode verwoord word. Hy verskil dus van Metz (1973) wat wel só 'n belang het. Hoewel Jüngel (1974:425) nie die politieke vooronderstellings van Metz ondersteun nie, maar ook nie die 'sosiale onbetrokkenheid' van Ritschl nie, het hy 'onsekerheid' of 'narratiewe teologie' 'n geskikte vorm sou wees om 'dogmatiese teologie', veral die kompleksiteit van God se menswording, te kan verwoord (kyk Mauz 2009:269-270). 1.Volgens Mauz (2009:265, voetnota 9$)$ het Otto Ritschl reeds in 1920 die begrip gebruik toe hy 'n onderskeid getref het tussen 'theologia
historica seu narrativa' en 'theologia dogmatica'.

2.Daar is ' $n$ bepaalde idealisering teenwoordig in die frase 'van mythos tot logos' met betrekking tot die konsep van 'narratiewe onskuld' (Wacker 1977:97). Geen stelling is sonder vooronderstellings nie (Mauz 2009:267). 
Hierteenoor het 'n ryk tradisie na aanleiding van die Yaleschool in die Sistematiese Teologie ontstaan. Hier kan onder andere na die werk van Gary Comstock (1987:687-717), en Stanley Hauerwas en Gregory Jones (1989) verwys word. Die invloed van die Yale-school kan ook in Duitsland in die werk van Knut Wenzel (1997) en Herman Deuser (1999) gesien word. Hoewel Mauz van oordeel is dat narratief nie die enigste 'taal' of 'modus' van die teologie is nie, is dit egter 'n belangrike komponent van 'God-talk'. Teo-logie as 'God-talk' neem verskillende vorme aan, onder andere mites, liedere, evangelie, psalm, legende, gebed, belydenis (confessio), geloofsbelydenis (credo), dogma, dialoog, kommentaar, konkordansie, joernaalartikel, monografie, opstel (essay) en resensie. In 'n sekere sin is daar onderliggend aan elkeen van hierdie vorme die 'narratief' van God se verhouding met 'n gelowige aanwesig.

Narratief is ' $n$ sentrale element in die Bybel, die basisdokument van die Christelike geloof. Die Bybel vertel verhale oor die skepping en die mensdom, van die reise van die volk Israel, van God wat in Jesus Christus mens geword het, van die eerste Christelike gemeenskappe, en in die apokaliptiese genre oor die einde van tyd en plek. Die taak van teologie as 'God-talk' is om hierdie verhale as individuele narratiewe in terme van die oorkoepelende narratief van God se handelinge met mense te vertolk. Wat hierdie 'vertolking' betref, onderskei Hermann Deuser (1999:22-24) in sy Kleine Einführung in die Systematische Theologie drie tipes narratiewe materiaal. Hy noem dit 'religieuse taal', verwysende na die dinamiese vergestalting van geloof soos 'n gebed of 'n lied, 'teologiese taal', verwysende na die akademiese refleksie op geloof, en 'konfessionele taal', verwysende na die taalgebruik in die kerk as instituut wat op albei vorige kategorieë betrekking kan hê. Die gevolg is dat die Christelike tradisie, wat uit die 'basisnarratief' van die Sache Jesu gegroei het, 'n rykdom van 'verhale' geproduseer het wat saam die geskiedenis van die kerk uitmaak. Episodes van hierdie oorkoepelende verhaal word tydens bepaalde momente vertel en oorvertel, byvoorbeeld in kategese, in voorbereiding vir belydenisaflegging en gedurende prediking. Narratiewe is ook vir die individuele Christen van belang. Dit artikuleer die bepaalde leefwyse en juis daardie leefwyse en hoekom nie ' $n$ ander een nie. Dit is ' $n$ verhaal wat met die verhaal van Jesus vervleg is, en wat vervleg is met ander verhale wat daaraan geknoop is.

Refleksie op die dinamiek van die geloofsgemeenskap, die rol van sosio-ekologiese konteks van mense, die insluiting van die Ander en die waarde van pluraliteit vorm die kern van die postmoderne narratiewe diskoers. In sy artikel 'Concept, image and story in systematic theology', skryf Fiddes oor die ontwerp van 'n Sistematiese Teologie wat die element van 'inclusive narrativity' insluit. Die narratief as modus van teologiebeoefening lewer bydraes tot Sistematiese Teologie deur 'deciding between concepts, enabling connections to be made, and in developing the story for the present age' (Fiddes 2009:17).

\section{Biografie as teologie}

Wat die narratiewe vorm betref, vind 'n mens sowel biografie as outobiografie (kyk Goldberg 1981-1982:62-95). Erik Borgman het in sy verwysing na die teologiese oortuiging van Johann Baptist Metz (1967:195-203, voetnota 18; kyk ook Van Wyk 2013:3 van 10) soos volg gewys op die belang van die biografie van 'n teoloog:

A theologian has to find God in her or his biography: only then is a credible theology possible ... One's own biography must take the form of a theological autobiography. Theology is credible whenever theologians do not just talk about God but while speaking about God also speak about themselves, and while writing, (re)write their own life as a place where God comes to light. (Borgman [1999] 2003:379)

Met die term 'outobiografiese kritiek' sluit die hermeneut Moore (1995:19) verskillende strategieë van ondersoekende lees in, soos 'personal criticism', 'confessional criticism' en 'autocritography' (Van Wyk 2013:4 van 10). Fowler (1995:232) wys daarop dat narratiewe epistemologie die gevolg daarvan is dat lesers verantwoordelikheid neem vir hulle eie interpretasies van data. Daar is twee benaderings wat ten opsigte van die outobiografiese-diskursiewe modus gevolg kan word, naamlik die idio-autobiographical en die metaautobiographical (Maldonado 1995:91). Idio-autobiographical verwys na wat algemeen gewoonlik onder (outo)biografie verstaan word, en dit is 'n vertelling oor sekere ervarings, gebeure en motiverings van 'n interpreteerder. Metaautobiographical verwys na 'data' wat op 'n 'onbewuste vlak' is, en behels die 'verhaal' van interaksies, intriges en kultuur, wat die konteks van die verteller of die mense oor wie vertel word, beïnvloed (kyk Van Wyk 2013:4 van 10). Fowler (1995:234) is daarom van mening dat in narratiewe diskoerse 'n mens nie altyd sekerheid het oor waar 'n 'biografie' eindig en waar 'n 'outobiografie' begin nie. Frege (1970:56-78) het gevolglik onderskei tussen die sense of the narrative (signatum) en die referent of the narrative (designatum). Die 'sense' verwys na die immanente betekenis van die narratief. Dit sluit kodes, wat te doen het met die leksikale betekenis van begrippe, asook die assosiasies wat gepaard gaan met die gewone gebruik van taal, in (Ricoeur 1984:56; vgl. Dreyer 2003:312$313,326-327)$. Omdat 'n narratief ook 'n 'referent' het, is daar in die narratief terugverwysings na die verlede en projeksies na die toekoms (vgl. Ricoeur 1981:171-176, 280-287).

In die 'life story' (Bybelse narratiewe, waarvan die Jesusverhaal fundamenteel is) is Christian storytelling nie om die Bybelverhale in jou eie lewensverhale toe te pas nie. Dit is 'n omgekeerde proses: 'n mens gaan vind jou lewensverhaal in die Bybelse verhale - 'n mens word 'einheimisch' met die Bybel (kyk Albrecht 1994; Schröder 1996). Dit gaan nie meer oor explicatio en applicatio nie, maar daaroor dat 'n mens se eie lewensverhaal kongeniaal is met die outentieke verhale in die Bybel (kyk ook Van Wyk 2012:2-3 van 9).

\section{Ricoeur (1984:50-52), in Time and narrative:}

onderskei drie aspekte in narratiwiteit: prefigurasie (die 'story of life') is die aktiwiteit van die outeur of verteller wat 'n teks 
skep, konfigurasie (strukturering van die data verkry uit eersgenoemde, die lewenstorie) dui op die betrokkenheid van die leser of hoorder, en refigurasie (die inbring van die eie verhaal na aanleiding van die voorafgaande strukturering van die data wat as relevant ervaar word) is die leser of hoorder se voortgaande lewe as 'n veranderde lewe. (Van Wyk 2013:3 van 10; vgl. Stiver 2001:56-78; Dreyer 2003:313-332)

Ricoeur (1984, vgl. [1989] 1995:186) noem die proses van prefigurasie, konfigurasie en refigurasie die hermeneutiese boog. Die doel van die hermeneutiek is om by die 'refigurasie' uit te kom, naamlik dat die leser of hoorder tot 'n eie nuwe narratief sal kom. Die eie lewensverhaal ('story of life') verkry sin in die interaksie met die verhale van ander (Van Wyk 2013:3 van 10, kyk ook Dreyer 2003:326). Hierdie interaksie is tegelyk partisipasie en transformasie:

... the quest for an ethics of character and a theology of character makes a demand upon the character of the theologian, and upon those who, reading, share the task. We are called thus to find our selves, our true selves, in the meeting with God which Christian faith celebrates. And these selves are irremediably varied selves. In this sense, we return from the lives we have examined to our own lives, the examiners become the examined, and our claim on our 'saints' becomes their many-sided claim upon us. (McClendon [1974] 1990:171)

Vervolgens word die lewe van die Duitse sistematiese teoloog Jürgen Moltmann, op narratiewe wyse beskryf deur die invloed van die twee wêreldoorloë op sy teologie te verken. Moltmann se teologie en ekklesiologie is 'n illustrasie van die uitleef van 'n emansipatoriese epistemologie. Dit het nie in ' $n$ vakuum ontstaan nie. In sy groot outobiografiese werk, A broad place ${ }^{3}$ ([2006] 2008:30), beskryf hy trouens hoe God hom in die konsentrasiekamp kom vind het, en dat sy ervarings van die oorlog die hermeneutiese sleutel tot sy lewe én teologie sou word (vgl. Moltmann 1997:2):

But what I have been sure of ever since my early experiences of death in the firestorm in Hamburg in 1943 was, and still is, the need to find an answer to the question, Why am I alive, and not dead like the others? Everything I have begun in my life was an attempt to answer this question. (Moltmann [2006] 2008:381)

\section{Jürgen Moltmann: 'n Narratief van versoenende verskeidenheid 'n Soeker na God, maar nie een van die populus nie}

Hy is in April 1926 in Hamburg gebore, wat as die 'tydperk tussen die oorloë' beskryf kan word. Sy jeug is gekenmerk deur verpligte deelname aan eers die 'Jungvolk' - die staat se jeugbeweging vir jonger seuns; en later ook aan die 'Hitler Jeug' - vir ouer seuns. Moltmann het homself na aanleiding van hierdie 'oorlogsterme' gekaraktiseer, en homself teenoor die rigiditeit wat daarmee verband hou, geplaas: 'I couldn't march in step and confused right and left'. Later het hy in terme van sy tydperk by die Hitler Jeugkamp gesê die ervaring het sy oortuiging versterk dat 'I was not born to be one of a mass' (Moltmann [2006] 2008:13).

Sy onmiddellike omgewing en konteks was geheel en al sekulêr. Die hele familie het een keer 'n jaar 'n kerkdiens bygewoon op Oukersaand, maar die bywoning van die diens het niks met die viering van die tyd te doen gehad nie. Die samekoms was om familiebande te vier. Nieteenstaande Moltmann se familie se apatie ten opsigte van die kerklike en godsdienstige lewe, is hy as adolessent saam met die res van sy skoolklas na 'n plaaslike predikant vir belydenisafleggingsklasse gestuur. Hy het in 1940 openbare belydenis van geloof volgens kerklike voorskrif gedoen. Dit het egter meer te doen gehad met formaliteit as met geloof. Sy oupa aan vaderskant, Johannes Moltmann, was 'n 'vrye denker' en het in die atmosfeer van die optimistiese vroeë jare van die Duitse ryk geblom. Hy het pamflette oor die Verligting geskryf wat teen die kerk gemik was (Moltmann 1905). Feuerbach se 'verligte' werke het Johannes en sy gesin van hulle geloof in God ontneem (Moltmann [2006] 2008:6). Moltmann se pa het sy hele lewe lank probeer om Johannes Moltmann se filosofiese notas en werke te begryp. Hy was entoesiasties oor die sogenaamde 'vrye' Duitse jeugbeweging. As gebore historikus het hy later 'n onderwyser geword en vir mense soos Helmut Schmidt (Duitse kanselier van 19741982) en sy vrou Loki Schmidt (Duitse omgewingskundige) klas gegee.

Die oupa Moltmann en Moltmann se pa was uiters belese. Hierdie nalatenskap van sy pa en oupa het eintlik vir Jürgen soos bagasie gevoel; hy het as kind tot en met twaalfjarige ouderdom gesukkel om 'n belangstelling in lees, kennis of studie te ontwikkel. As gevolg daarvan het hy minderwaardig gevoel:

For me, childhood was not an entirely happy time. It was often one in which 'I didn't know what to do'. Compared with my tall father, I was too small. Sent to school early, I was always the youngest in the class. (Moltmann [2006] 2008:11)

Hy was lusteloos en aandagafleibaar in die klas, en geen van sy onderwysers het enige entoesiasme by hom gewek nie. Sy ouma aan moederskant het egter op daardie stadium ingegryp en hom 'menslik' behandel. Sy het nie op hom neergesien nie, hom aangespoor, perdryklasse betaal en hom saam met haar na deftige en uitgelese geselskap geneem. Hierdie ervaring van sy 'waarde' as 'mens' het 'n blywende indruk op hom gemaak.

Die waardering en erkenning van die waarde van alle mense het die paradigma van sy lewe en teologie geword. Wedersydse respek en die vryheid om jou eie 'mens' te wees; dit is die wye ruimte van die Drie-enige God waar daar vir almal plek is (Moltmann [1980] 1981:xiii). Sy ouma se erkenning van sy menswees het hom in beweging gebring en hy het besluit om in vakke waarin sy pa hoegenaamd nie presteer het nie, uit te styg - chemie, fisika en wiskunde. Sy pa was 'n kenner van Duits, Latyn en geskiedenis, en het die mense rondom hom deeglik bewus gemaak van sy eie 'meerderwaardige kennis'. Hy sou later volledig uit sy pa se skaduwee tree toe sy pa in 1939 vir militêre diensplig opgeroep is.

Hy het sy toelatingseksamen afgelê om sy opleiding voort te sit, maar in Februarie 1943 is hy saam met sy hele skoolklas 
opgekommandeer om lugmag- 'helpers' te wees. Die verwoesting en dood wat hy in Julie daardie jaar in Hamburg meegemaak het, het ook 'n blywende merk op hom gelaat. Meer as 40000 lewens het met 'Operasie Gomorra' in die slag gebly (Brunswig [1983] 2003). Die Britse Royal Air Force het Hamburg vir nege nagte lank gebombardeer. Hy en sy mede- (jong) 'helpers' het tussen die rook (dag) en vlamme (nag) gelewe en die hele tyd oor verkoolde lyke geklim. Hulle het mense gesien wat verwese aan enkele besittings, soos 'n boek, probeer vasklou het. Die laaste aand het ' $n$ bom ontplof op die platform waarop 'n klompie van Moltmannhulle gestaan het. Sy vriend, Gerhard Schopper, wat langs hom gestaan het, is grusaam deur die houtsplinters van die platform uitmekaar geruk (vgl. Moltmann [2006] 2008:17).

I was left alone in that place of death ... During that night I cried out to God for the first time in my life and put my life in his hands. My question was not 'Why does God allow this to happen?' but 'My God, where are you?' And there was the other question, the answer to which I am still looking for today: Why am I alive and not dead, too, like the friend at my side? I felt the guilt of survival and searched for the meaning of continued life. During the night I became a seeker after God. (Moltmann 1997:2)

Net voor hy in 1944 formeel vir diensplig opgeroep is, besoek sy pa hom in die opleidingskamp en vertel vir hom van die massamoord van die Jode. Moltmann is verbitter toe hy die nuus hoor:

Why the appalling silence of Christians? Why did Christians turn a blind eye with such deadly consequences? Was it conscious or unconscious anti-Semitism which kept Christians mute when the Jews were 'taken away'? Was it the misused doctrine of the 'two kingdoms' which helped the churches to 'keep out of things'? (Moltmann [1967] 2000:115)

Tydens sy diensplig was hy in verskeie aanvalle en skermutselinge betrokke. In hierdie tyd beleef hy weereens die pynlike ervaring van die verlies van 'n kameraad. Hierdie kameraad is in Moltmann se arms dood. Die vraag wat Moltmann daardie nag in 1943 in Hamburg gevra het, het weer by hom gespook - 'what am I going on living for?' (Moltmann 1997:1-3).

In Februarie 1945 is sy bataljon na die gebied waar die Britse soldate hulle offensief sou loods. Daar aangekom, ontstaan 'n skietgeveg en hulle posisie word deur die Britte ingeneem. Moltmann en 'n paar ander soldate soek in 'n nabygeleë huis skuiling. Hy slaag daarin om hom vir 'n paar dae te versteek, maar sy onversorgde en honger toestand dwing hom om die grens te probeer bereik. Op een van die woud se paadjies loop hy in 'n Britse soldaat vas en gee homself onmiddellik oor. Dit was die begin van die drie jaar wat hy in krygsgevangenekampe deurgebring het. Van die eerste kamp onthou hy die mistroostigheid en die depressie wat in die lug gehang het. Hulle het nou wel die oorlog oorleef, maar weereens, 'what was the point of it all?' (Moltmann [2006] 2008:26). Omdat daar nie veel in die kamp te doen was nie, was daar baie tyd vir besinning, en in die aande het Moltmann eensaam en uitgelewer gevoel aan die herinneringe en die verwoestende donker. Later in dieselfde jaar is hy na 'n kamp in Skotland oorgeplaas.

\section{Die waarde van menswees}

In Skotland, en veral in Norton Camp, is die eertydse Duitse soldate gasvry en sonder verwyt of blaam ontvang en behandel (Moltmann 1997:3, 2012). Vir 'n tweede keer in sy lewe ervaar hy die 'geskenk' van menswaardigheid:

True, we had numbers on our backs and prisoners' patches on our trousers, but we felt accepted as people. This humanity in far-off Scotland made human beings of us once more. We were able to laugh again. (Moltmann [2006] 2008:29; vgl. Moltmann 1997:4-8)

'n Kwarteeu later het hy oor die waarde van lag vir spiritualiteit geskryf. 'Grief' word met 'play' teengewerk, soos aangetref in 'Risus Paschalis' - 'Easter laughter'. Tydens die Middeleeue was dit die gebruik in sommige RoomsKatolieke kerke in Beiere dat die priester gedurende die viering van Pase komiese stories sou vertel en die hele gemeente saamgelag het (McCoy 2000). In sy Theology of joy ${ }^{4}$ skryf Moltmann oor die rou wat met speelsheid (die 'Easter laughter') teengewerk word:

Only those who are capable of joy can feel pain at their own and other people's suffering. A man who can laugh can also weep. A man who has hope is able to endure the world and to mourn ... So Easter freedom does not permit us to escape from the world or to forget about it. Rather it leads us critically to accept the world situation with its unacceptable moments and patiently to bring about change in the world so that it may become a place of freedom for humankind. Thus both the laughter of Easter and the sorrow of the cross are alive in liberated human beings ... They are not only laughing with those who laugh and weeping with those who weep ... but they are also laughing with the weeping and weeping with the laughing as the Beatitudes of Jesus recommended. Their game always points critically at the oppressors. It therefore constantly provokes harassment by those who prohibit laughter because they fear liberty. (Moltmann [1971] 1973:52-53)

In Skotland het nuus en foto's van die oorlog en die Nazikonsentrasiekampe hulle geleidelik bereik. Moltmann was verslae toe hy homself en ander Duitse soldate deur slagoffers se oё bekyk het (Woodbridge 2010:107; vgl. Moltmann [2006] 2008:29). Op daardie oomblik het ook Moltmann die 'Das Volk' verbygegaan: 'For me, every patriotic feeling for Germany - "holy Fatherland" - collapsed and died' (Moltmann [2006] 2008:29). Die gewigslas van die skaamte oor sy eie volk het nog nooit werklik sy skouers verlaat nie (Moltmann 1997:4). Dit het daartoe bygedra dat hy enige verband tussen 'volk' en 'kerk' en God gedekonstrueer het, en later in sy teologie kritiek gelewer het op die 'monotheistic justification of monarchist and absolute power ... the Christian doctrine of the Trinity is different. It does not link the eternal God with a godlike ruler' (Moltmann [1967] 2000:303).

Twee belangrike gebeurtenisse het hom egter uit hierdie depressie oor sy 'volk' se wandade gelig - die eerste was die vriendelike behandeling van die Skotte en die ander was die ontvangs van 'n Bybel. 'n Kapelaan het dit op 'n dag daar tussen hulle kom uitdeel. Terugskouend sou die klompie

4.Oorspronklike Duitse titel Die ersten Freigelassenen der Schöpfung: Versuche über die Freude an der Freiheit und das Wohlgefallen am Spiel. 
van hulle op daardie stadium sigarette meer gewaardeer het. Daar gebeur egter met Moltmann iets wat as 'n totale en rigtingveranderende paradigmaskuif beskryf kan word. In die byna argelose lees van die boek trek ' $n$ spesifieke gedeelte sy aandag-Psalm 39 se hulpkreet - 'hoor tog my gebed, Here, luister tog na my hulpgeroep; moet nie koud staan teenoor my trane nie' (die 1983 Afrikaanse vertaling). Hy het dit oor en oor gelees. Toe lees hy die evangelie volgens die beskrywing van Markus en toe hy Jesus se doodskreet 'hoor', 'my God, waarom het U my verlaat?', het die oortuiging in hom al hoe sterker geword dat hier iemand is wat ' $n$ mens verstaan, wat saam met jou in jou hulpkreet aan God is, en wat in dieselfde verlatenheid geleef het waarin jy nou leef. Hier is iemand wat vir hom, Moltmann, verstaan - die mede-lydende wat jou lyding saam met jou dra: 'Christ's God forsakenness showed me where God is. Where he had been with me in my life, and where he would be in the future' (Moltmann 1997:5). Hy is gevul met die dapperheid om weer te leef, in die vooruitsig van 'God's "wide space where there is no more cramping"' (Moltmann [2006] 2008:30) - 'n belangrike hermeneutiese sleutel tot sy teologie. Daarom verklaar hy dat Jesus vir hom in daardie oorlogskamp kom soek en hom gevind het.

Geleidelik het hy begin besef dat sy gevangenskap nie van korte duur sou wees nie, en het hy daarom aansoek gedoen om na 'n opleidingskamp gestuur te word waar jong gevangenes hulle finale skoolverlaterseksamen kon aflê. In 1946 is hy na Norton Camp in Cuckney, naby Mansfield in Nottinghamshire oorgeplaas. Daar kon die gevangenes opleiding as onderwysers of predikante ontvang. Daar was 'n goeie biblioteek en Moltmann het gelees asof hy nog nooit die kans gehad het of weer sou hê nie. Hy lees sy eerste teologiese boek, dié van Reinhard Niebuhr, The nature and destiny of man.

Nadat hy die skoolverlaterseksamen in 1947 suksesvol afgelê het, het hy besluit om nie soos sy voorvaders 'n onderwyser te word nie, maar eerder 'n predikant. Die kurrikulum van die predikantsopleiding was uitgebreid en hy het al die lesings wat daar oor verskillende teologiese onderwerpe aangebied was, bygewoon. Teoloë soos Willem Visser 't Hooft en Martin Niemöller het die kamp besoek en lesings aangebied. Dit was 'n tydperk waarin Moltmann intens intellektueel verkeer het, en sy proses van 'her-vermensliking' wat in die Skotse kamp begin is deur Skotse families se hartlikheid, is voortgesit alhoewel nie voltooi nie - dit sou eers heelwat later plaasvind.

Sedertdien het hy sy kollektiewe krygsgevangenekampervarings gedurende daardie tyd dikwels in die verhaal van Jakob se stryd met God by die Jabbok-stroom teruggevind. In die voorwoord van sy latere werk, The source of life: The Holy Spirit and theology of life 5 , skryf hy oor sy 'wrestling with God' in 'A personal meditation on Jacob's struggle at the Brook Jabbok, following Genesis 32:25-32' (Moltmann 1997:1-9): '... I suffered under the 'hidden face of God', which the Jews call hester panim ... and I sensed the 'light of God's countenance' when it became light in my life' (Moltmann [2006] 2008:34).

5.Oorspronklike Duitse titel Quelle des Lebens: der Heilige Geist und die Theologie des Lebens.
Hierdie ervarings was egter ook die oorsprong van sy klem op die versoenende inklusiwiteit van die Christelike geloof. Dit blyk uit 'n gebeurtenis wat hy meen sy lewe totaal omgekeer het - hy en ' $n$ paar ander van die 'gevangenes' is genooi om die eerste SCM-konferensie (Student Christian Movement) wat na die oorlog plaasgevind het, by te woon. In plaas van die verwagte oordeel wat hy as Duitser in vrees en bewing te wagte was, word hy en die ander as broers in Christus verwelkom en eet, drink, sing en bid hulle saam met die ander wat so ver as van Australië en Nieu-Seeland gekom het: 'All at once I perceived that the Christian faith is a great reconciling force, which sets standards even in the world of politics ... In Christ there is no East or West ...' (Moltmann [2006] 2008:34).

Op 22-jarige ouderdom keer Moltmann na 'n verwoeste Hamburg terug. Dit was nie meer die tuiste wat hy agtergelaat het nie. Tog geniet hy die vryheid van beweging wat hy nou gehad het, en gaan voort om soveel as moontlik te lees, onder andere Heidegger se Sein und Zeit (1926). Hy moes bepaalde lesings bywoon in voorbereiding op studie aan die teologiese fakulteit in Göttingen. Hy vind dat hy meestal teleurgesteld is met die kwaliteit daarvan, vergeleke met die lesings en opleiding wat hy in Norton Camp gehad het. Een van sy dosente, Hellmut Traub, het wel 'n indruk op hom gemaak (Moltmann 1967 [2000]87). Traub het homself volledig in Karl Barth se teologiese tradisie tuisgevind en ook by hom gestudeer (vgl. Ulrichs 1997:119-122). Later sou hy as lid van die Belydende Kerk (Bekennende Kirche) vervolgde mense en diegene wat in die konsentrasiekampe gely het, se belange ook sy eie maak. Dit het 'n blywende indruk op Moltmann gemaak (kyk die rol van die Belydende Kerk as protes teen die offisiële Lutherse kerk, en veral die kerk se verdraagsaamheid jeens Nazi-ideologie (Holloway 1995:294; Paulgaard 1999).

In die daaropvolgende tyd het die teoloog Hans Joachim Iwand ' $n$ besondere indruk op Moltmann gemaak en een van sy belangrikste leermeesters geword (McDougall 2005:11, Winn \& Heltzel 2009:26-39). Iwand is merkbaar deur Karl Barth se teologie beïnvloed (vgl. Meeks 1974:15-53; Von Balthasar [1951] 1992:381; Morrison 2004:187-213; Gregory 2006) en was 'n leier van die destydse onwettige predikanteopleiding-seminarie van die Belydende Kerk (Seim 1999). Moltmann het hom as 'n entoesiastiese mentor beleef en het só onder 'n besondere indruk van Luther se teologie van die kruis gekom (Moltmann [1967] 2000:87). Eintlik het hierdie teologie, soos deur Iwand beliggaam, die grondslag vir Moltmann se The crucified God ${ }^{6}$ gevorm:

Since I first studied theology, I have been concerned with the theology of the cross ... it has been the guiding light of my theological thought. This no doubt goes back to the period of my first concern with questions of Christian faith and theology in actual life, as a prisoner of war behind barbed wire. I certainly owe it to the unforgettable lectures on Reformation theology I heard from Hans-Joachim Iwand. (Moltmann [1973] 1974:i)

Iwand's doctrine of justification went right to our hearts, godless and God-forsaken as we felt after our wartime experiences. (Moltmann [2006] 2008:42, vgl. Moltmann [1973] 1974:i-ii).

6.Oorspronklike Duitse titel Der gekreuzigte Gott. 


\section{Die oopgaan van 'wye ruimte' en 'n voortgesette ekumeniese gerigtheid}

Moltmann se kollektiewe ervarings het veroorsaak dat hy nie sy teologie in isolasie van die wêreld kon beoefen nie. Alhoewel hy teen 1953 'n gedoktoreerde teoloog was, het hy steeds geen tuiste in die Duitse kerk gevind nie. Danksy Weber het Moltmann die Calvinistiese tradisie liefgekry en het hy Elisabeth, sy vrou, na die Verenigde Kerk van Pruise gevolg (Moltmann [2006] 2008:53). Vir 'n kort tydperk was hulle albei in Oos-Duitsland, die Duitse Demokratiese Republiek, werksaam, maar het uiteindelik nie daarin geslaag om verblyfpermitte te verkry nie. Hulle is terug na WesDuitsland waar die kerk in Wesfale Moltmann as studentetutor aanvaar het. Hulle vind 'n 'wye ruimte' in die Bremense Protestantse kerk waar hy in 1954 as predikant georden is. Hierdie kerk het die Reformatoriese belydenisse gehandhaaf, maar terselfdertyd die vryheid van elke gemeente in geloof, belydenis en leer gerespekteer. Dit het beteken dat Moltmann hom binne hierdie tradisie op die Barmen-Verklaring, wat teen Nasionaal-Sosialisme gerig is (Hockenos 2004:23), kon beroep en ook só georden is.: 'So, I became "Reformed"' (Moltmann [2006] 2008:61). Later, rondom 1958, sou hy in die strate van Wuppertal, waar hy tot die Calvinistiese predikante-opleiding-seminarie toegelaat is, saam met ' $n$ paar ander kandidate van die seminarie aan protesoptogte namens Gustav Heinemann (later president van Wes-Duitsland) se Gesamt-deutsche Volkspartei, deelneem (Müller 1990:20-45).

Vir hom is publieke teologie egter tegelyk ook politieke teologie. Hy het betrokke geraak by 'n Duits-Poolse gemeenskap wat gemoeid was met die versoening tussen beide gemeenskappe. In 1962 gaan hy saam met die komitee van hierdie gemeenskap vir die eerste keer Pole toe (die Berlynse Muur is toe reeds in 1961 opgerig). In Maidanek, die konsentrasiekamp naby Lublin, staar Moltmann na die put waarin tot 10000 mense per dag geskiet is en wou hy op daardie oomblik in die afgrond van skaamte in verdwyn. Maar hy vertel van 'n prentjie wat in sy geestesoog verrys het (vgl. Moltmann, in McDougall 2005:xiii):

I looked into the world of the resurrection and saw all these dead men, women, and children coming towards me. Since then I have known that God's history with Auschwitz and Maidanek has not been broken off, but goes further with the victims and with the perpetrators. Without hope for the 'new earth in which righteousness dwells' (2 Peter 3.13), this earth, which has suffered Treblinka and Maidanek, would be unendurable. (Moltmann [2006] 2008:84)

Publieke teologie hou egter direk met ' $n$ inklusiewe teologie en 'n verruimende ekklesiologie verband. In 1963 raak hy betrokke by die vierde Faith and Order-kongres in Montreal. Die ontmoeting met teoloë van ander denominasies en van die Derde Wêreld was vir hom uiters belangrik, omdat Duitse teologie volgens hom selfgemoeid en selfgekonsentreerd was. Teologie is nie net 'for our own church and our own country' nie, maar is 'theology for the whole of Christendom on earth' (Moltmann [2006] 2008:85).

\section{Teologie van lewenservaring en met sosiale relevansie}

Tot en met sy aftrede was Moltmann gemoeid met die uitleef van 'n teologie vir almal, en ook vir die Ander. Vir hom was die kern van hierdie teologie die besef dat hy geen enkele saak, ook in sy teologie, net vanuit een perspektief (veral die 'eie' perspektief - in aansluiting by die voorafgaande) kan benader, of daaroor argumenteer, of tot gevolgtrekkings kan kom nie. Dit het beteken dat hy:

... wanted to resolve critically the naive self-centredness of one's thinking. Of course I am a European, but, European theology no longer has to be Eurocentric. Of course I am a man, but my theology does not have to be androcentric in its emphasis. Of course I am living in the so-called First World, but my theology does not therefore have to reflect the ideas of those at the top, but should make the voice of the oppressed heard. (Moltmann [1980] 1981:xii)

Hy beklemtoon dat 'waarheid' nie 'n selfgesentreerde saak is nie. 'Ek' het nie die waarheid (en niemand anders nie). Waarheid is te vinde in ongehinderde dialoog - 'in dialogue the truth frees men and women for their own conceptions and their own ideas' (Moltmann [1980] 1981:xiii). In hierdie dialoog is gemeenskap (koinonia) en vryheid 'n eenheid, gemeenskap in wedersydse respek en resiproke 'partisipasie' en vryheid in die reg om jou eie opinie te hê en jou instemming te betuig of nie te betuig nie. Dit is hoe daar in die lig van iets soos oorlog, soos 'n, Auschwitz-tydperk' en daarna, oor God nagedink en gepraat kan word. Vir Moltmann was die kernsaak ' $n$ teologie 'with its face turned towards the world' (vgl. Metz [1968] 1969:83).

In 'n plurale, postmoderne wêrelddorp is dit die verskeidenheid van narratiewe wat dialoog en gemeenskap moontlik maak. Dit is die verskeidenheid van mense wat 'einheimisch' met die Bybel word en 'n verskeidenheid verhale wat in die Bybelse verhale teruggevind word, wat 'n dinamiese, sosiaal relevante, transformerende teologie skep. Geloof is 'waarheid as ontmoeting' (Brunner [1943] 1964:1), en teologie is 'faith seeking understanding' [geloof, soekende na verstaan] (Anselmus van Kantelberg [1033-1109]; Dean 1951:33; vgl. Migliore [1992] 2004:1). Om in staat te wees om 'n teoretiese uiteensetting te bied van wat geglo word (dogmatiek), beteken dan 'om saam te weet' (dogmatiek) en dan na mekaar te luister (vgl. Van Wyk 2013:1 van 8) (etiek). Dit bring die refigurasie mee, 'n voortgaande lewe as 'n veranderde lewe. Jürgen Moltmann se lewe en teologie, sy narratief, is by uitstek ' $n$ voorbeeld daarvan - 'n voorbeeld van die waarde van narratiwiteit vir sistematiese teologie:

Christian doctrine is 'validated, so far as it can be validated by the evidence of these lives' ... The existence of their witness, however, makes Christian atonement a real issue, a live option, and confronts us with that issue here and now. (McClendon [1974]: 80, 148; 1990: viii, [beklemtoning oorspronklik])

\section{Erkenning Mededingende belange}

Die outeur verklaar dat sy geen finansiële of persoonlike verbintenis het met enige party wat haar nadelig kon beïnvloed in die skryf van hierdie artikel. 


\section{Literatuurverwysings}

Albrecht, C., 1994, Schleiermachers Theorie der Frömmigkeit: Ihr wissenschaftliche Ort und ihr systematischer Gehalt in den Redden, in der Glaubenslehre und in der Dialektik, De Gruyter, Berlin. http://dx.doi.org/10.1515/9783110878981

Anselmus [1033-1109] 1951, Proslogium; Monologium, An appendix in behalf of the fool, by Gaunilon, a monk of Marmoutier; and Cur Deus, transl. S.N. Dean, Open publishing company, La Salle Illinois.

Borgman, E., [1999] 2003, Edward Schillebeeckx: A theologian in his history - Volume 1: A Catholic theology of culture (1914-1965), transl. J. Bowden, Continuum, London.

Brunner, E., [1943] 1964, Truth as encounter, Westminister Press, Philadelphia.

Brunswig, H., [1983] 2003, Feuersturm über Hamburg. Die Luftangriffe auf Hamburg im 2. Weltkrieg und ihre Folgen, Motor Buch Verlag, Stuttgart.

Comstock, G.L., 1987, 'Two types of narrative theology', Journal of the American Academy of Religion 55, 686-717.

Deuser, H., 1999, Kleine Einführung in die Systematische Theologie, UTB, Stuttgart.

Dreyer, Y., 2003, "n Teoretiese inleiding tot narratiewe hermeneutiek in die teologie', HTS Teologiese Studies/Theological Studies 59(2), 313-332. http://dx.doi. org/10.4102/hts.v59i2.661

Fiddes, P.S., 2009, 'Concept, image and story in systematic theology', International Journal of Systematic Theology 11(1), 23 pages. http://dx.doi.org/10.1111/j.14682400.2008.00420.x

Fowler, R.M., 1995, 'Taking it personally: A personal response', Semeia 72, 231-238.

Frege, G., 1970, 'On sense and reference', in P. Geach \& M. Black (eds.), Translations from the philosophical writings of Gottlob Frege, transl. M. Black, pp. 56-78. Blackwell, Oxford.

Goldberg, M., 1981-1982, Theology and narrative: A critical introduction, Abingdon, Nashville.

Gregory, W.A., 2006, The promise of righteousness: Hans Joachim Iwand's Christology in response to Karl Holl's theology, Princeton Theological Seminary, Princeton.

Hauerwas, S.M., \& Jones, G.L., 1989, Why narrative? Readings in narrative theology, Wipf \& Stock, Grand Rapids.

Heidegger, M., 1962, Sein und Zeit, SCM Press, London.

Hockenos, M.D., 2004, A church divided: German Protestants confront the Nazi past, Indiana University Press, Bloomington.

Holloway, J.Y., 1995, Barth, Barmen and the confessing church today: Katallagete, E. Mellen Press, Lewiston.

Jüngel, E., 1974, 'Metaphorische Wahrheit.Zur Hermeneutik einer narrativen Theologie', Evangelische Theologie, Metapher. Zur Hermeneutiek religiöser Sprache, 71-122.

Jüngel, E., [1977] 1992, Gott als Geheimnis der Welt. Zur Begründung der Theologie des Gekreuztigten im Streit zwischen Theismus und Atheismus, Mohr Siebeck, Tübingen.

Maldonado, R.D., 1995, 'Reading Malinche reading Ruth: Toward a hermeneutics of betrayal', Semeia $72,91-110$.

Mauz, A., 2009, 'Theology and narration: Reflections on the narrative theology-debate and beyond', in S. Heinen \& R. Sommer (eds.), Narratology in the age of cross disciplinary narrative research, Berlin, Bereitgestellt von UZH Hauptbibliothek/ ZB Zürich (UZH Hauptbibliothek / ZB Zuerich), Angemeldet 172.16.1.226, http:// dx.doi.org/10.5167/uzh-27661

McClendon, J.W., [1974] 1990, Biography as theology, Trinity Press International, Philadelphia.

McCoy, J.M., 2000, 'Risus paschalis sermons', a sermon on Psalm 126:1-6 and Mark 16:1-8, preached by Dr John M. McCoy, at Highland Park Presbyterian Church, University Boulevard, Dallas, Texas, on Easter Sunday, April 23, 2000, viewed 29 June 2012, from http://www.newcelebrations.com/risus_paschalis_sermons.htm

McDougall, J.A., 2005, Pilgrimage of love: Moltmann on the Trinity and Christian life, Oxford University Press, New York.

Meeks, D.M., 1974, Origins of theology of hope, Fortress Press, Philadelphia.

Metz, J-B., 1967, 'Kirche und Welt im Lichte einer "Politischen Theologie"', in J-B. Metz 1997, Zum Begriff der neuen Politischen Theologie 1967-1997, pp. 195-203, Grünewald, Main.

Metz, J-B., [1968] 1969, Zur Theologie der Welt, transl. W. Glen-Doepel, Grünewald, Main.

Metz, J-B., 1973, 'Kleine Apologie des Erzählens', Concilium 9, 334-342.

Migliore, D.L., [1992] 2004, Faith seeking understanding, Eerdmans Publishing Company, Grand Rapids.
Moltmann, J., 1905, Vom künftigen Gott oder Psychotheismus statt Kosmotheismus, Leipzig.

Moltmann, J., [1971] 1973, Theology of joy, transl. R. Ulrich, SCM Press, London.

Moltmann, J., [1973] 1974, The Crucified God, transl. R.A. Wilson and J. Bowden, SCM Press, London.

Moltmann, J., [1980] 1981, The Trinity and the kingdom: The doctrine of God, transl. M. Kohl, SCM Press, London.

Moltmann, J., [1997], The source of life, transl. M. Kohl, SCM Press, London.

Moltmann, J., [1967] 2000, Experiences in theology. Ways and forums of Christian Theology, transl. M. Kohl, SCM Press, London.

Moltmann, J., [2006] 2008, A broad place, an autobiography, Fortress Press, Minneapolis.

Moltmann, J., 2012, 'From physics to theology: A personal story', CIS-Faraday-lecture delivered at the Faraday Institute of Science and Religion, St Edmund's College, Cambridge, 14 February, viewed 03 August 2012, from https://www.st-edmunds. cam.ac.uk/faraday/Multimedia.php?...22

Moore, S.D., 1995, 'True confessions and weird obsessions: Autobiographical interventions in literary and biblical studies', Semeia 72, 19-50.

Morrison, J.D., 2004, 'Barth, Barthians, and evangelicals: Reassessing the question of the relation of the Holy Scripture and the Word of God', Trinity Journal 25(2), 187-213.

Müller, J.,1990, Die Gesamtdeutsche Volkspartei. Entstehung und Politik unter dem Primat nationaler Wiedervereinigung 1950-1957, Droste-Verlag, Düsseldorf.

Paulgaard, J., 1999, 'The confessing Church in Germany, 1933-1945', History 285(6), $16-36$.

Ricoeur, P., 1981, Hermeneutics and the Human Sciences, Cambridge University Press, Cambridge.

Ricoeur, P., 1984, Time and narrative, vol. 1, transl. K. McLaughlin and D. Pellauer, Chicago University Press, London/Chicago. http://dx.doi.org/10.7208/ chicago/9780226713519.001.0001

Ricoeur, P., [1989] 1995, 'Pastoral praxeology, hermeneutics, and identity', in M.I. Wallace (ed.), Figuring the sacred: Religion, narrative and imagination, transl. D. Pellauer, pp. 303-315, Fortress Press, Minneapolis.

Ritschl, D., 1976, “'Story” als Rohmaterial der Theologie', in J.O. Jones (ed.) 'Story' als Rohrmaterial der Theologie, pp. 7-41, Kaiser, München.

Ritschl, D., 1984, Logik der Theologie. Kurze Darstellung der Zusammenhänge theoligischer Grundgedanken, Kaiser, München. PMid:6083673

Ritschl, D., 2005, 'Nachgedanken zum "Story"-Konzept. Die Koagulation wiedererzählter "Stories" auf dem Weg zu differierenden theologischen Lehren', Theologische Zeitschrift 61, 78-91.

Schröder, M., 1996, Die kritische Identität des neuzeitliche Christentums: Schleiermachers Wesenbestimmung der christliche Religion, Mohr Siebeck, Tübingen. (BHTh 96)

Seim, J., 1999, Hans-Joachim Iwand. Eine Biographie, Gütersloher Verlag-Haus, Kaiser.

Stiver, D.R., 2001, Theology after Ricoeur: New directions in hermeneutical theology, Westminister John Knox Press, Louisville.

Ulrichs, H.G., 1997, Hellmut Traub, 'Unerschrocken zur Zeit oder zur Unzeit': Beobachtungen eines Predigers, Zeugen und Lehrers zur kirchlichen Zeitgeschichte. Mit Beitrage von Gerhard Sauter und Hinrich Stoevesandt, Foedus, Wuppertal.

Van Wyk, T., 2012, 'Kerkwees in die saeculum vandag, Deel 1: Eenheid te midde van veelheid', HTS Teologiese Studies/Theological Studies 68(1), Art. \#1281, 9 pages. http://dx.doi.org/10.4102/hts.v68i1.1281

Van Wyk, T., 2013, 'Om saam te weet en dan te luister: Edward Schillebeeckx se begrip Deus Humanissimus as die kerk se gewete', HTS Teologiese Studies/Theological Studies 69(1), Art. \#1983, 10 pages. http://dx.doi.org/10.4102/ hts.v69i1.1983

Von Balhasar, H.U., [1951] 1992, The theology of Karl Barth, exposition and interpretation, Ignatius Press, San Francisco.

Wacker, B., 1977, Narrative Theologie?, Kösel, München.

Weinrich, H., 1973, 'Narrative Theologie', Concilium 9, 329-334.

Wenzel, K., 1997, Zur Narrativität des Theologischen. Prolegomena zu einer narrative Texttheorie in soteriologischer Hinsicht, Lang, Frankfurt am Main.

Winn, C.T.C. \& Heltzel, P. G., 2009, 'Before Bloch there was Blumhardt: A thesis on the origins of the theology of hope', Scottish Journal of Theology 62(1), 26-39. http:// dx.doi.org/10.1017/\$0036930608004614

Woodbridge, N.B., 2010, 'Revisiting Moltmann's theology of hope in light of its renewed impact on emergent theology', Journal of the South African Theological Seminary 9, 106-113. 